\title{
The Effect of Media on Biomass and Oil Production in Botryococcus braunii Strains Kossou-4 and Overjuyo-3
}

\author{
Khalid A. Al-Hothaly,2, Aidyn Mouradov¹, Abdulatif A. Mansur',3, Brian H. May, \\ Andrew S. Ball1, Eric M. Adetutu ${ }^{1 *}$ \\ ${ }^{1}$ School of Applied Sciences, RMIT University, Bundoora, Australia \\ ${ }^{2}$ Department of Biotechnology, Faculty of Science, Taif University, Taif, Kingdom of Saudi Arabia \\ ${ }^{3}$ Department of Environmental and Natural Resources Engineering, Faculty of Engineering, Azawia University, \\ Azawia, Libya \\ ${ }^{4}$ School of Health Sciences, RMIT University, Bundoora, Australia \\ Email: ${ }^{*}$ eric.adetutu@rmit.edu.au
}

Received 27 January 2015; accepted 9 February 2015; published 17 February 2015

Copyright (C) 2015 by authors and Scientific Research Publishing Inc.

This work is licensed under the Creative Commons Attribution International License (CC BY).

http://creativecommons.org/licenses/by/4.0/

(c) () O)

\section{Abstract}

The green algae Botryococcus braunii is widely recognized as a source of oil, including hydrocarbons. However, the slow rate of growth $B$. braunii hampers its commercial development. This study addresses this by examining the effects of three growth media on biomass and oil production in two B. braunii Race B strains, Kossou-4 and Overjuyo-3. Growth of B. braunii strains in BG11 medium resulted in significantly higher growth $(2.3-4.2$ and 2.9 - 6.0 fold increases in Kossou-4 and Overjuyo-3 respectively) compared to the JM and BBM-3N media after 15 days. A similar trend was obtained when biomass was measured indirectly using optical density (OD) and chlorophyll fluorescence. Oil production was also significantly higher in BG11 whether measured as oil weight or absorbance (ODs at 680 and $750 \mathrm{~nm}$ ). However, the presence of extracellular oil was shown to increase absorbance values making OD measurements less reliable than dry weight assays. Maximum recovery of oil was recorded when hexane was used as solvent compared to hexane-isopropanol and heptane. These results suggest that BG11 is the best growth medium for these two strains under the conditions of this experiment.

\section{Keywords}

\section{B. braunii, Race B, Media, Biomass, Oil Production}

\footnotetext{
${ }^{*}$ Corresponding author.

How to cite this paper: Al-Hothaly, K.A., Mouradov, A., Mansur, A.A., May, B.H., Ball, A.S. and Adetutu, E.M. (2015) The Effect of Media on Biomass and Oil Production in Botryococcus braunii Strains Kossou-4 and Overjuyo-3. International Journal of Clean Coal and Energy, 4, 11-22. http://dx.doi.org/10.4236/ijcce.2015.41002
} 


\section{Introduction}

The potential use of microalgae for the production of biofuels has recently received significant attention [1] because of the search for renewable alternatives to fossil fuel. The advantages of using microalgae as an alternative source of biofuel compared to other algae and plants include a high rate of growth (10 - 50 times faster than terrestrial plants), the fact that they are not food crops and they have a rapid $\mathrm{CO}_{2}$ fixation rate [2]. Microalgae can also accumulate high concentrations of hydrocarbons and are able to produce both biofuels and valuable coproducts [3]. Biofuels that originate from photosynthetic organisms such as microalgae may be carbon-neutral and renewable [4].

The microalga, Botryococcus braunii is one of the most widely studied organisms. B. braunii is characterized by unusually high hydrocarbon content, thought to reach $86 \%$ of the dry weight of the cell. It is a slow growing, colonial, fresh water microalgae [5]. In order to produce biomass and oil from B. braunii at a commercial scale, its growth conditions (in terms of medium that enhances growth and biomass production) need to be determined. To maximize biomass production, microalgae require light energy for biomass production and $\mathrm{CO}_{2}$ fixation, while the culture media must supply both macronutrients and micronutrients to enable the algae to grow [6]. Although some research has been done on oil (hydrocarbon) production by B. braunii [7], studies of the effects nutrients and growth media on biomass production are comparatively few [8].

Biomass and oil production in $B$. braunii has been investigated in a number of studies using different media such as Z8, BG11, BBM and CHU 13. However, most studies have been conducted using a single medium. For example, the growth of $B$. braunii and two other species of microalgae in blue green algae (BG11) medium have been studied, with very high biomass and lipid content for B. braunii being reported [9]. In a photo-bioreactor, $B$. braunii 765 strain was observed to have good growth in BG11 at $25^{\circ} \mathrm{C}$ under continuous light [10]. Apart from BG11, other media have been used for B. braunii cultivation [11]. B. braunii (SKU: AC-1006 strain) has been cultured in BBM and its modified form (BBM-3N) with higher biomass and lipid production in BBM-3N compared to BBM. B. braunii (SKU \& AC-1006 strains) also grew well at $25^{\circ} \mathrm{C}$ in bold basal medium (BBM) and in BBM with added nitrogen and vitamins i.e. BBM-3N medium [11]. Duplicate experiments were conducted for each medium with maximum growth being found in the BBM-3N medium. A comparison of $16 \mathrm{~B}$. braunii strains grown in Jaworski's Medium $(\mathrm{JM})$ at $23^{\circ} \mathrm{C}$ for 34 days $(12 \mathrm{~h} \mathrm{light;} 12 \mathrm{~h}$ dark) showed that, out of the 16 Race A, B and L strains evaluated, hydrocarbon content was highest in the three Race B strains, Kossou 4, Overjuyo 3 and Paquemar [12].

Few reports evaluating the growth efficiency of $B$. braunii in different media are available. The growth of $B$. braunii LB 572 and SAG 30.81 in four media-bold basal medium (BBM), bold basal with ammonium carbonate (BBMa), BG11 and modified Chu 13 medium for 6 weeks has been evaluated [13]. The investigators found the highest biomass production in BG11 medium for both strains and both strains also produced high hydrocarbon (oil) yields in BG11 [13]. However, [2] suggested that CHU 13 medium was better for B. braunii growth than either BG11 or BBM media. Another study [14] compared the growth of $B$. braunii in four autotrophic media (CHU13, Z8, BBM, and BG11) at $25^{\circ} \mathrm{C}$ and found that the highest biomass was produced in BG11 medium. Reports on other microalgae (for example Ankistrodesmus falcatus) have shown better growth in BBM compared to BG11 medium [15]. However, there are no reports comparing the growth of $B$. braunii in BG11 medium to the growth in JM medium despite the fact that both media have been used to culture the microalgae [9] [12]. Therefore in this study, we will assess biomass and oil production in two high hydrocarbon-yielding strains of B. braunii, Kossou-4 and Overjuyo-3 when grown in the three different media, JM, BG11 and BBM3N in order to determine the best medium for the growth of these strains.

Previous studies of $B$. braunii have used dry weight (DW) as the primary measure of biomass [10]. In addition, changes in optical density (OD) have been used as a measure of growth. This method has the advantage of being less time-consuming than measuring microalgal dry weight. The following OD wavelengths have been used in previous studies: $550 \mathrm{~nm}$ for B. braunii SKU, AC-1006 [11], $750 \mathrm{~nm}$ for B. braunii BOT-22 [16], 680 $\mathrm{nm}$ for B. braunii FACHB-357 231 [17] and 750/680 nm for Chlorella vulgaris [18]. Other methods that have been used for measuring biomass include chlorophyll content [10] [11] [19]. For B. braunii Kossou 4 and Overjuyo 3, the only published study is that of [12] which focussed on hydrocarbon yield. Therefore, it is important to determine the best method for measuring the biomass of these two strains.

A number of methods have been reported for the solvent extraction of oil from microalgal biomass. Chloroform-methanol is a frequently used solvent system [20], but the carcinogenic effects of chloroform are of con- 
cern (NLM-Toxnet http://toxnet.nlm.nih.gov National Library of Medicine, USA). Hexane is commonly used due its low cost and good extraction efficiency [21] while heptane has also been used [22] as well as hexane-isopropanol 2:3 (v/v) [20]. In order to investigate which solvent was the best for extracting oil from the two $B$. braunii strains, the less toxic solvents-isopropanol, hexane and heptane were selected for use in this study (NLM-Toxnet http://toxnet.nlm.nih.gov National Library of Medicine, USA (accessed 13082014).

The specific aims of this study are to i) investigate the ability of two strains of Botryococcus braunii Race B to grow in three different growth media, ii) compare five methods for measuring biomass in the two B. braunii strains, and iii) compare three methods for extracting oil from biomass produced by the two $B$. braunii strains. Based on the results obtained, the best of these media, growth assays and solvents for oil extraction for commercial production of the $B$. braunii strains will be determined.

\section{Materials and Methods}

\subsection{Microalgae Source}

Two race B strains of $B$. braunii were selected for use in this study. The two strains selected have been classified into race $\mathrm{B}$, with members of this race being known for their high level of hydrocarbon production. Both strains were obtained from Flinders University and originated from Pierre Metzger's collection. The Kossou-4 strain was originally from the Ivory Coast and shows a brownish colouring while Overjuyo-3 was from Bolivia and is green in colour [23].

\subsection{Apparatus}

A POLARstar Omega (BMG TABTECH) plate reader was used to measure optical density and chlorophyll fluorescence. A Ratek incubator shaker was used to provide continuous shaking of cultures. To observe biomass and oil production, fluorescence microscopy was carried out using a Leica DM 2500 microscope equipped with a Leica DFC 310 FX camera. Magnification was 100×; excitation was at $543 \mathrm{~nm}$ and emission 555 - $650 \mathrm{~nm}$.

\subsection{Media and Culture Preparation}

Three growth media, i) Blue Green medium (BG11) ii) Bold base medium (BBM-3N) and iii) Jaworski's medium (JM) were used. BG11 were prepared according to [10]. BBM-3N medium was prepared according the recipe provided on the Culture Collection of Algae and Protozoa (CCAP) website:

(http://www.ccap.ac.uk/media/documents/3N_BBM_V_000.pdf) and JM medium was prepared according to [24]. The components of each medium are shown in Table A1.

\subsection{Experimental Design}

Six hundred millilitres of each of the medium were added to Erlenmeyer flasks (2000 mL). For Kossou-4 and Overjuyo-3, the experiments were conducted in replicates for each medium. Flasks were inoculated with an aliquot $\left(6 \mathrm{~mL}\right.$ ) of Kossou-4 or Overjuyo-3, which corresponded to $0.04 \mathrm{~g} \cdot \mathrm{L}^{-1}$ (dry weight) of microalgal culture.

\section{Culture Conditions}

Inoculated culture media were incubated on a Ratek incubator shaker, which was set to a rotation frequency of $100 \mathrm{rpm}$ at $25^{\circ} \mathrm{C}$ for 15 days. Continuous white fluorescent light illumination at intensity of $54 \mu \mathrm{mol}$ photons $\mathrm{m}^{-2} \cdot \mathrm{s}^{-1}$ was provided.

\subsection{Measurements of Biomass Production}

Sampling was carried at 3-day intervals, with replicate samples being subject to four different assays. The assays were as follows: optical density at a wavelength of at 680 and $750 \mathrm{~nm}$, chlorophyll fluorescence at $430 \mathrm{~nm}$ and dry weight.

\subsubsection{Optical Density (OD)}

Optical density provides a measure of algal growth. Optical density was determined using a POLAR star Omega Microtitre plate reader. Algal suspension $(200 \mu \mathrm{L})$ was added to each selected well (in replicates) in a 96 well 
microtitre plate. Before taking the individual reading, the plate was shaken continuously for $30 \mathrm{~s}$. Light absorbance was measured at a wavelength of 680 and $750 \mathrm{~nm}$. Higher absorbance values indicate greater growth [18].

\subsubsection{Chlorophyll Fluorescence}

A POLARstar Omega (BMG TABTECH) microtitre plate reader was also used to measure chlorophyll fluorescence. Culture solutions $(200 \mu \mathrm{L})$ were taken and inoculated in replicates into selected wells in a 96 well black microtitre plate. The plate was shaken for $30 \mathrm{~s}$ before fluorescence was read at $430 \mathrm{~nm}$. Higher fluorescence values indicate greater growth according to [25].

\subsubsection{Dry Weight (DW)}

An aliquot $(100 \mathrm{~mL}$ ) of each algal solution was filtered using a MILLIPORE Filter ( $45 \mu \mathrm{m}, 47 \mathrm{~mm}$ ) of predetermined weight via a standard vacuum pump. The filter paper-culture complex was weighed before and after drying at $65^{\circ} \mathrm{C}$ until a constant weight was attained. The weight of the filter paper was deducted from the total weight of samples (before and after drying) to determine the dry weight of the microalgal biomass, which was then expressed as percentage dry weight values according to [26].

\subsection{Oil Extraction}

\subsubsection{Hexane}

To extract oil from B. braunii, strains Kossou-4 and Overjuyo-3, the method described by [27] was used. Briefly, algal dry weight was measured gravimetrically in a freeze-dried sample. N-hexane $(10 \mathrm{~mL}$, Sigma-Aldrich; Australia) was added to freeze-dried algal cells before being put in a sonication bath for 5 min to disrupt the cells. Finally the upper layer was transferred into a pre-weighed Agilent glass tube. To determine the amount of oil produced, the n-hexane was removed by evaporation with pure $\mathrm{N}_{2}$ gas in a fume hood. Replicate samples were evaluated and the oil contents measured gravimetrically.

\subsubsection{Hexane-Isopropanol}

The protocol used for solvent extraction of oil in the two strains was based the method of [20] which involved the use of a mixture of hexane/isopropanol (3:2) (Sigma-Aldrich; Australia). Freeze dried algal biomass were mixed with solvent $(10 \mathrm{~mL})$ and incubated overnight [20]. The samples were placed in a water bath for sonication and the rest of the procedure as described in Section 2.6.1 was followed.

\subsubsection{Heptane}

Heptane (Sigma-Aldrich; Australia) was used to extract oil from the two strains of B. braunii. Day 15 cultures were harvested and freeze dried. Heptane $(10 \mathrm{~mL})$ was added to the cells and samples placed in a water bath for sonication and the rest of the procedure as described in Section 2.6.1 was followed [28] [29].

\subsubsection{Absorbance by Extracted Oil}

In order to assess the effects of oil on absorbance values determined by OD measurements, the absorbance values of $200 \mu \mathrm{L}$ of extracted oil were determined at 680 and $750 \mathrm{~nm}$. Oil samples extracted by hexane from cultures grown in the three media were used.

\subsection{Statistical Analysis}

One-way analysis of variance (ANOVA) was used to determine the differences between the levels of growth between media at different time points for each strain of B. braunii. A p value of 0.05 or less was considered as the statistically significant value. ANOVA tests were conducted for each measurement of biomass. Post-hoc multiple comparisons were conducted using Tukey's HSD. Data analysis was conducted using IBM SPSS 21 for Windows (SPSS Inc., USA).

\section{Results}

\subsection{Microalgal Growth}

Both strains grew in each of the media under the growth conditions of $25^{\circ} \mathrm{C}$ temperature, under continuous light 
and agitation at 100 rpm (Figure 1). Figure 1(a), Figure 1(c) and Figure 1(e) shows the growth of Kossou-4 in BG11, JM and BBM 3N media respectively. Figure 1(b), Figure 1(d) and Figure 1(f) shows the growth of Overjuyo-3 strain in BG11, JM and BBM 3N media respectively.

\subsection{Biomass Estimation}

\subsubsection{Dry Weight}

By day 15, the dry weight of Kossou-4 grown in the BG11 medium was the highest, reaching $\sim 2.19 \mathrm{~g} \cdot \mathrm{L}^{-1} \mathrm{com}-$ pared with $0.97 \mathrm{~g} \cdot \mathrm{L}^{-1}$ in JM medium and $0.52 \mathrm{~g} \cdot \mathrm{L}^{-1}$ in BBM 3N medium (Figure 1(a)). ANOVA for dry weight $\mathrm{mg} \cdot \mathrm{L}^{-1}$ values at day 15 for Kossou-4 showed a significant difference between media. Tukey's HSD showed significant differences between BG11 and JM (p < 0.01), between BG11 and BBM-N3 $(p<0.01)$ and between JM and BBM-N3 ( $<0.05)$.

At day 15, the dry weight of Overjuyo-3 grown in the BG11 medium reached $\sim 2.53 \mathrm{~g} \cdot \mathrm{L}^{-1}$ compared with 0.87 $\mathrm{g} \cdot \mathrm{L}^{-1}$ in the JM medium and $0.42 \mathrm{~g} \cdot \mathrm{L}^{-1}$ in BBM 3N medium (Figure $1(\mathrm{~b})$ ). ANOVA for dry weight $\left(\mathrm{mg} \cdot \mathrm{L}^{-1}\right.$ ) at day 15 for Overjuyo-3 showed a significant difference between media.

\subsubsection{Optical Density (OD at $680 \mathrm{~nm}$ )}

Growth measurement at an optical density of $680 \mathrm{~nm}$, indicated that Kossou-4's growth was greater in the BG11 medium than in other media. Figure 1(c), shows the sharp rise in the growth of Kossou-4 in BG11 medium at this O.D $(680 \mathrm{~nm})$ while the growth in the other two media were found to be similar but lower than was observed in BG11. There were significantly different results between all three media at day 15 . The OD values at $680 \mathrm{~nm}$ in BG11 $(0.56 \mathrm{~nm})$ were 1.7-fold higher than in JM $(0.33 \mathrm{~nm})$ and 2.1 fold higher than in BBM-N3 me$\operatorname{dium}(0.26 \mathrm{~nm})$.

At day 15, Overjuyo-3 grown in BG11 medium reached an OD value of 0.58 (1.6 and 1.9 fold higher than in JM and BBM-N3 respectively) compared with 0.37 in JM medium and 0.31 in BBM 3N medium (Figure 1(d)). The ANOVA for Optical density at $680 \mathrm{~nm}$ at Day 15 for Overjuyo-3 showed significant differences between media. Tukey's HSD showed significant differences between BG11 and JM $(\mathrm{p}<0.05)$, between BG11 and BBM-N3 ( $<0.05)$ and between JM and BBM-N3 $(\mathrm{p}<0.05)$.

\subsubsection{Optical Density (OD at $750 \mathrm{~nm}$ )}

When measured at an OD of $750 \mathrm{~nm}$, there was a gradual increase in algal growth of Kossou-4 over a 15-day time-frame. Growth in the BG11 medium was higher than in the other two media (JM and BBM). At day 15, both Kossou-4 (Figure 1(e)) and Overjuyo-3 (Figure 1(f)) showed a similar trend with the highest growth in BG11, followed by JM and BBM-N3 media with significant differences being observed $(\mathrm{p}<0.05)$.

\subsubsection{Chlorophyll Fluorescence (CF at $430 \mathrm{~nm}$ )}

The chlorophyll fluorescence readings of Kossou-4 samples are shown in Figure 1 (g). The samples showed steady increases in CF measured at $430 \mathrm{~nm}$ over the 15 days of growth. At day 15, the chlorophyll fluorescence (CF) of Kossou-4 culture grown in the BG11 medium reached $650 \mathrm{~nm}$ compared with $330 \mathrm{~nm}$ in the JM medium and $202 \mathrm{~nm}$ in the BBM 3N medium (Figure 1(g)). Tukey's HSD showed significant differences between growth in BG11 and JM ( $<<0.01)$, between BG11 and BBM-N3 p < 0.01) and between JM and BBM-N3 ( $<$ 0.01). A similar trend was observed in Overjuyo-3 (Figure 1(h)).

\subsection{Oil Extraction Efficiencies of Solvents (Dry Weight)}

\subsubsection{Hexane}

At day 15, the total oil extracted by n-hexane from Kossou-4 cultures grown in the BG11 medium was 762.3 $\mathrm{mg} \cdot \mathrm{L}^{-1}\left(0.76 \mathrm{~g} \cdot \mathrm{L}^{-1}\right)$ compared with $395.6 \mathrm{mg} \cdot \mathrm{L}^{-1}\left(0.40 \mathrm{~g} \cdot \mathrm{L}^{-1}\right)$ of oil extracted in the $\mathrm{JM}$ medium and 287.3 $\mathrm{mg} \cdot \mathrm{L}^{-1}\left(0.29 \mathrm{~g} \cdot \mathrm{L}^{-1}\right)$ oil extracted in the BBM $3 \mathrm{~N}$ medium (Table 1$)$. At day 15 , the total oil extracted by nhexane from Overjuyo-3 cultures grown in the BG11 medium was slightly lower; $644.5 \mathrm{mg} \cdot \mathrm{L}^{-1}\left(0.65 \mathrm{~g} \cdot \mathrm{L}^{-1}\right)$ (BG11), $382.4 \mathrm{mg} \cdot \mathrm{L}^{-1}\left(0.38 \mathrm{~g} \cdot \mathrm{L}^{-1}\right)(\mathrm{JM})$ and $268.6 \mathrm{mg} \cdot \mathrm{L}^{-1}\left(0.27 \mathrm{~g} \cdot \mathrm{L}^{-1}\right)$ (BBM-N3) (Table 1). There were significant differences between the amount of oil recovered from microalgae grown in different media. Tukey's HSD showed significant differences between BG11 and JM ( $p<0.05)$, between BG11 and BBM-N3 $(\mathrm{p}<0.05)$ and between JM and BBM-N3 media $(\mathrm{p}<0.05)$. 


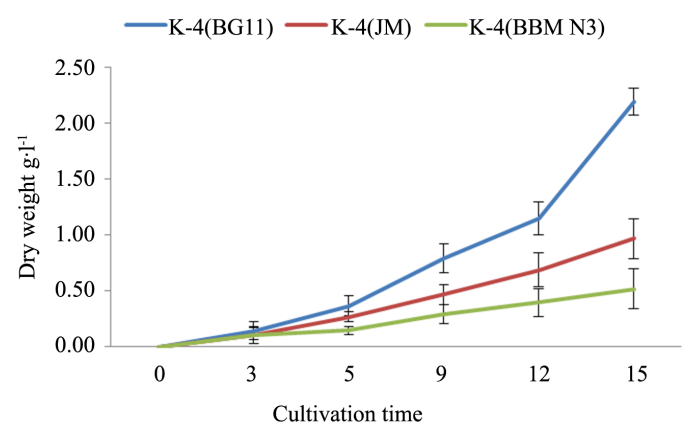

(a)

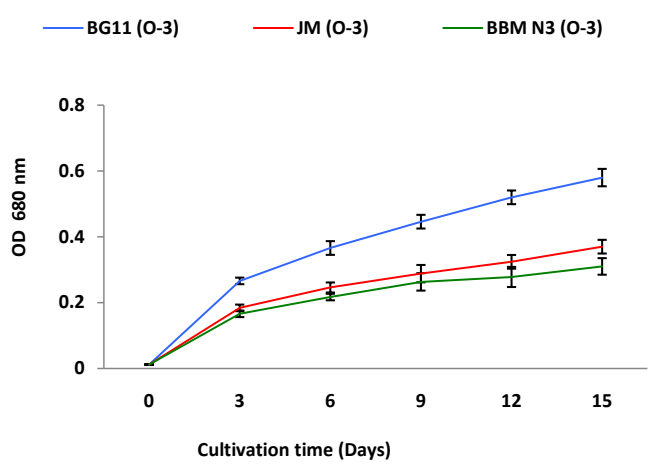

(c)

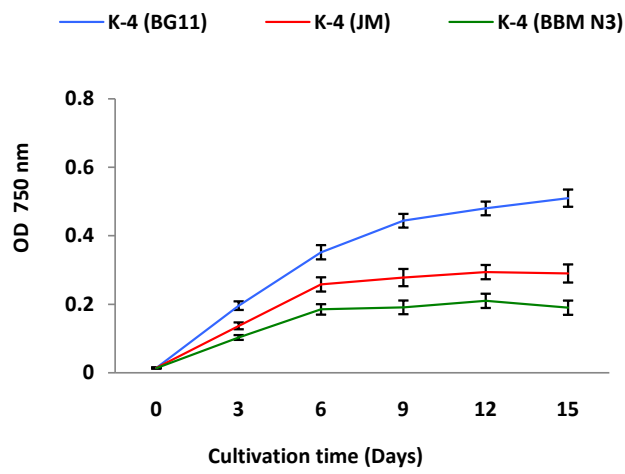

(e)

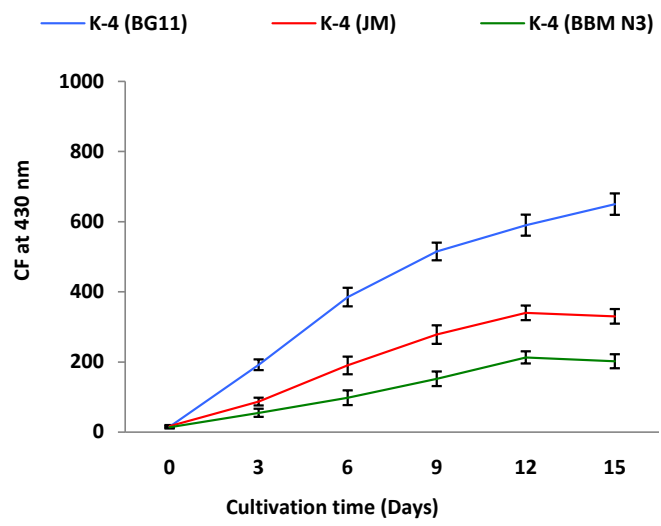

(g)

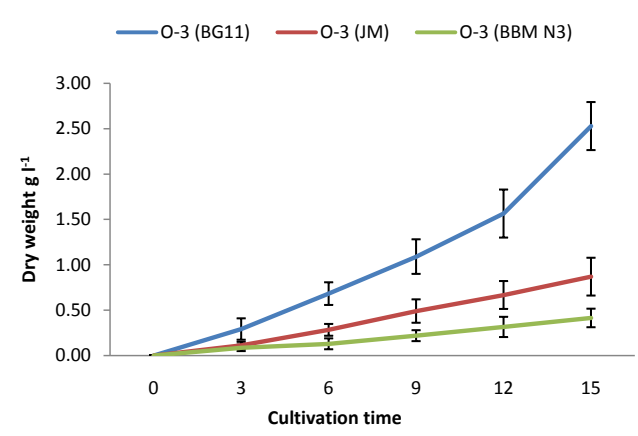

(b)

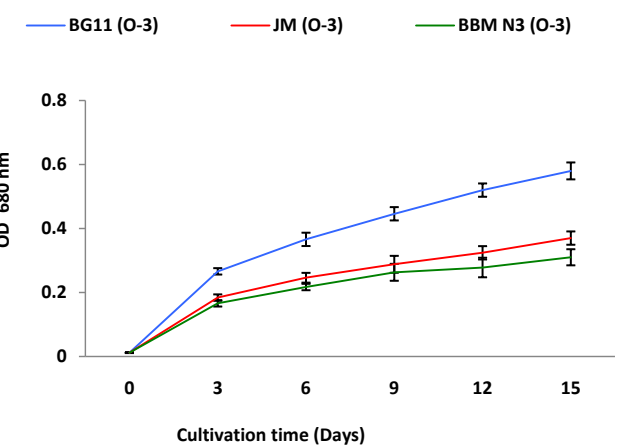

(d)

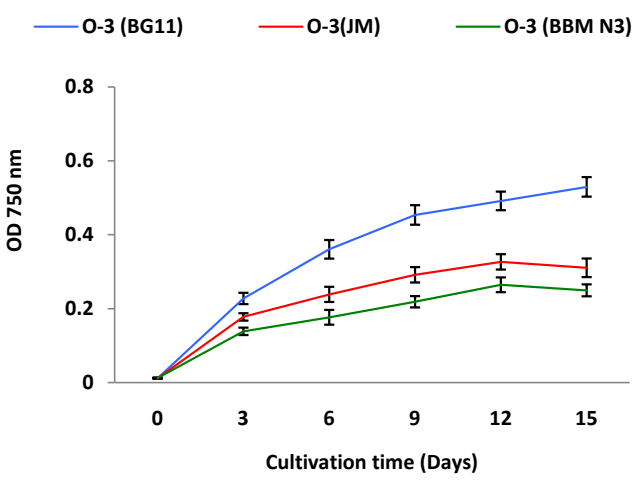

(f)

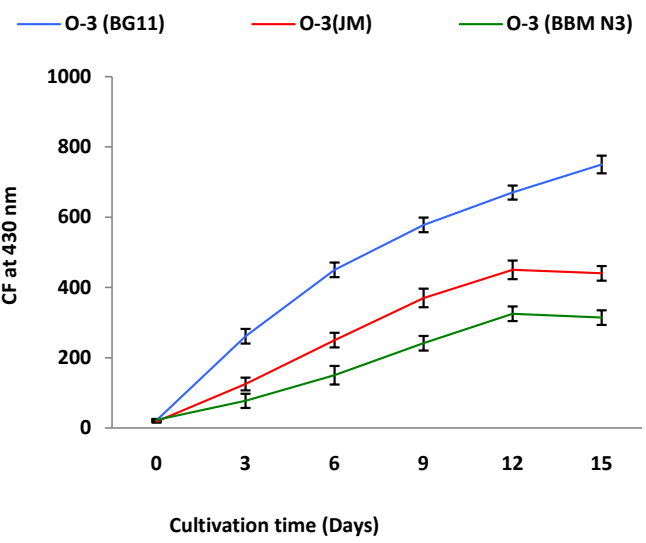

(h)

Figure 1. Effects of growth media on the dry weight (a) and (b), ODs at 680 (c) and (d) and $750 \mathrm{~nm}$ (e) and (f) and chlorophyll fluorescence (g) and (h) (at $430 \mathrm{~nm}$ ) of B. braunii strains Kossou-4 (K-4) and Overjuyo-3 (O-3) over 15 days. 


\subsubsection{Hexane-Isopropanol}

At day 15, the total oil weight extracted with hexane and isopropanol from Kossou-4 cultures grown in the BG11 and other medium was lower than the total oil recovered from hexane extractions; BG11 $\left(528.5 \mathrm{mg} \cdot \mathrm{L}^{-1}\right.$ or $\left.0.53 \mathrm{~g} \cdot \mathrm{L}^{-1}\right)$, JM (361.4 $\mathrm{mg} \cdot \mathrm{L}^{-1}$ or $\left.0.36 \mathrm{~g} \cdot \mathrm{L}^{-1}\right)$ and BBM $3 \mathrm{~N}\left(235.6 \mathrm{mg} \cdot \mathrm{L}^{-1}\right.$ or $\left.0.24 \mathrm{~g} \cdot \mathrm{L}^{-1}\right)$ (Table 1$)$. Statistical analyses (Tukey's HSD) showed significant differences between BG11 and JM (p < 0.05), between BG11 and BBM-N3 $(p<0.05)$ and between JM and BBM-N3 media $(\mathrm{p}<0.05)$. The same trend was observed in Overjuyo-3 cultures with a lower amount of total oil recovered compared to hexane with the weight of recovered oil being significantly different between media $(\mathrm{P}<0.05)$ (Table 1$)$.

\subsubsection{Heptane}

At day 15, the total oil extracted by n-heptane from Kossou-4 cultures grown in the BG11 and other media was the lowest amongst the three solvents tested; BG11 (345.5 $\mathrm{mg} \cdot \mathrm{L}^{-1}$ or $\left.0.35 \mathrm{~g} \cdot \mathrm{L}^{-1}\right)$, JM $\left(222.3 \mathrm{mg} \cdot \mathrm{L}^{-1}\right.$ or $\left.0.22 \mathrm{~g} \cdot \mathrm{L}^{-1}\right)$ and BBN $3 \mathrm{~N}\left(176.1 \mathrm{mg} \cdot \mathrm{L}^{-1}\right.$ or $\left.0.18 \mathrm{~g} \cdot \mathrm{L}^{-1}\right)$ (Table 1). Tukey's HSD showed significant differences between the three different media and a similar trend was observed in Overjuyo-3 cultures.

\subsection{Measurement of the Absorbance by Extracted Oil}

The effects of extracted oil at day 15 (no algal biomass) on absorbance reading were assessed. The absorbance of oil extracted from Kossou- 4 cultures grown in the BG11 medium reached 0.090 at 680 and 0.080 at $750 \mathrm{~nm}$ compared with 0.072 at 680 and 0.059 at $750 \mathrm{~nm}$ in the JM medium and 0.060 at 680 and 0.0450 at $750 \mathrm{~nm}$ in the BBM 3N medium (Figure 2(a)). The absorbance values of oil extracted Overjuyo-3 cultures grown in the three media are shown in Figure 2(b). The results showed that the presence of oil (without any biomass) in the media caused a detectable increase in optical density readings.

\section{Discussion}

In previous studies, B. braunii strains had been cultured in a range of media and were reported to have grown successfully in JM [24], BBM-N3 (http://www.ccap.ac.uk/media/documents/3N_BBM_V_000.pdf) and BG11 media [10]. However there is a gap in knowledge regarding the media which is optimal for biomass yield for $B$. braunii race B strains Kossou-4 and Overjuyo-3. This study fills this gap by showing that microalgal cultures in BG11 resulted in the highest biomass yield (assessed by dry weight) amongst the three media tested. The same trend was observed in biomass assay through OD, and chlorophyll fluorescence for both strains. There are many reports on the growth of $B$. braunii strains in different but single medium [11] [13] [14] [30] although none of

Table 1. Extraction of oil produced by B. braunii strains Kossou-4 and Overjuyo-3 cultures in different media using different solvents.

\begin{tabular}{|c|c|c|c|}
\hline \multirow{2}{*}{ Extraction by different solvents } & \multirow{2}{*}{ Media } & Kossou-4 & Overjuyo-3 \\
\hline & & Oil extraction $\mathrm{mg} \cdot \mathrm{L}^{-1}$ & Oil extraction $\mathrm{mg} \cdot \mathrm{L}^{-1}$ \\
\hline \multirow{3}{*}{ Hexane } & BG11 & $762.3( \pm 0.23)$ & $644.5( \pm 0.21)$ \\
\hline & $\mathrm{JM}$ & $395.6( \pm 0.11)$ & $382.4( \pm 0.21)$ \\
\hline & BBM 3N & $287.3( \pm 0.06)$ & $268.6( \pm 0.21)$ \\
\hline \multirow{3}{*}{ Hexane \& Isopropanol } & BG11 & $528.5( \pm 0.15)$ & $530.9( \pm 0.35)$ \\
\hline & $\mathrm{JM}$ & $361.4( \pm 0.25)$ & $239.4( \pm 0.35)$ \\
\hline & BBM 3N & $235.6( \pm 0.05)$ & $221.5( \pm 0.35)$ \\
\hline \multirow{3}{*}{ Heptane } & BG11 & $345.5( \pm 0.12)$ & $318.3( \pm 0.20)$ \\
\hline & $\mathrm{JM}$ & $222.3( \pm 0.12)$ & $206.5( \pm 0.20)$ \\
\hline & BBM 3N & $176.1( \pm 0.12)$ & $167.2( \pm 0.20)$ \\
\hline
\end{tabular}

Note: Day 15 cultures used, $(n=3)$ and standard deviations shown. 


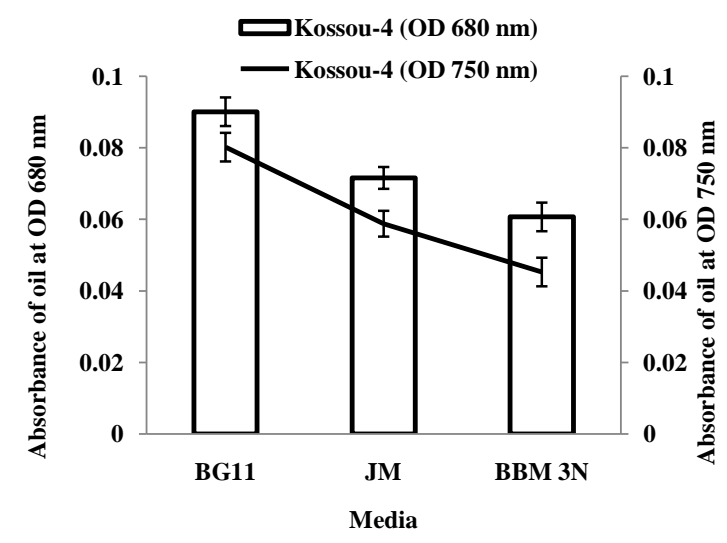

(a)

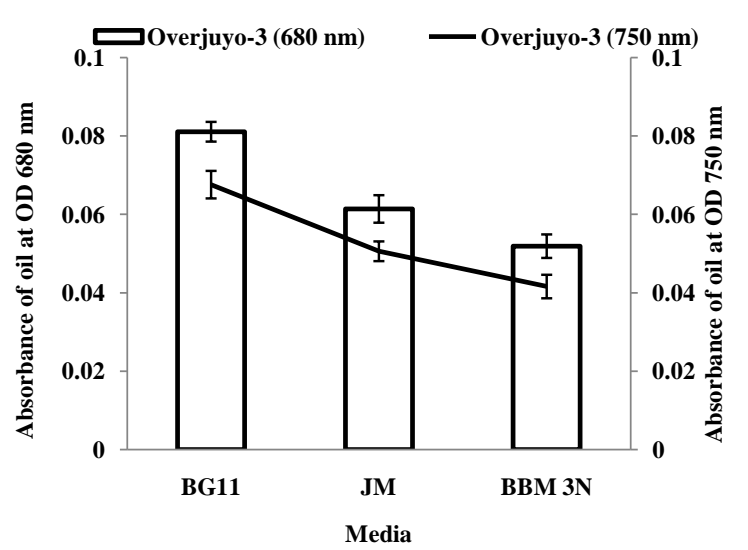

(b)

Figure 2. Absorbance values of extracted oil in different media at ODs of 680 and $750 \mathrm{~nm}$ (a) \& (b) in B. braunii strains Kossou-4 (K-4) and Overjuyo-3 (O-3).

these studies compared all the three media used in this study or used the same strains. One key difference between BG11 and the other media tested was the relatively high content of sodium nitrite $\left(1.5 \mathrm{~g} \cdot \mathrm{L}^{-1}\right)$ in BG11 and this may have contributed to the enhanced microalgal growth observed in this medium [13]. In addition, BG11 was richer in key nutrients that favoured the growth of these strains, which were absent in the other media. A detailed analysis of the BG11 media components showed that it was rich in some trace elements and these were absent in JM and BBM 3N media. For example, $\mathrm{CuSO}_{4} \cdot 5 \mathrm{H}_{2} \mathrm{O}, \mathrm{Co}\left(\mathrm{NO}_{3}\right)_{2} \cdot 6 \mathrm{H}_{2} \mathrm{O}$ and $\left(\mathrm{C}_{6} \mathrm{H}_{8} \mathrm{FeNO}_{7}\right)$ are present in BG11 but absent in the other media (Table A1).

With regards to optical density measurements, previous studies have measured OD at different wavelengths but these studies did not use B. braunii strains Kossou-4 and Overjuyo-3. For example, four wavelengths (438, 540, 678 and $750 \mathrm{~nm}$ ) have been used to measure microalgal growth and similar patterns of change were found for each OD in each of the algae tested [31]. In general, higher OD readings were found at the lower wavelengths. In our study, the readings were also taken at $680 \mathrm{~nm}$ rather than at $750 \mathrm{~nm}$ alone for both strains. Griffiths et al. (2011) also used OD of 680 and 750 to investigate the effects of the pigment content of Chlorella vulgaris on estimates of growth and reported that OD 750 readings were much less affected by changes in pigment than were readings at $680 \mathrm{~nm}$ [18]. In our experiment, only Kossou-4 produced pigments and there was no evidence of the OD 680 readings being affected, but there was only a little pigmentation in the Kossou- 4 since the experiment was conducted during the early growth stages. Therefore it is possible that an effect of pigmentation of Kossou- 4 on OD could arise with a longer duration of the experiment and consequently greater pigmentation. This issue should be considered when using OD as an estimate of biomass in Kossou-4.

Comparing dry weight assays with OD assays, different growth patterns were observed in the first six days. While dry weight assays showed very little growth from day 0 to day 6, OD assays at 680 and $750 \mathrm{~nm}$ appear to show that most microalgal growth (>60\% of total growth) had occurred within this time frame. The same trend was observed in CF assays for both strains. Therefore, optical density measurements appear to over-estimate microalgal biomass for these two Botryococcus braunii strains compared to dry weight assays. OD based assays are relatively easier to carry out than dry weight based assays and have been used in many studies for estimating the biomass of microalgae [11]. Figure 2 shows that there were absorbance readings when only extracted microalgal oil (no biomass) was present in the culture medium. Therefore, the reason for this over estimation appears to be related to the presence of oil in the culture. Given that both Kossou- 4 and Overjuyo- 3 were producing oil extracellularly during the OD based biomass assay, it was possible that absorbance associated with the oil contributed to the overestimation of biomass by optical density based methods. Therefore, OD based assay methods may not be appropriate for estimating biomass in oil producing microalgae. If the research questions were focussed on only changes in the biomass of microalgae that does not produce hydrocarbons (oil), then OD measurements would be faster and more appropriate. However, if other assays are planned (such as as says for total oil, squalene and botryococcene production) in addition to biomass assay, dry weight based assays would be more appropriate.

With respect to oil (hydrocarbon) production, the highest concentration was observed in both strains in BG11 
medium, irrespective of the solvent used or assay method. Although Overjuyo-3 showed the higher biomass, oil production was higher in Kossou-4 in all measurements, although the differences were not substantial. This was similar to the result by another group of investigators [12] which showed a slightly lower hydrocarbon content for Overjuyo-3 compared to Kossou-4. The reason for this unclear, however it might be related to the genetic make-up of the Kossou-4 strains.

Previous studies had involved the use of a variety of solvents and solvent combinations for extracting oil from microalgae. These include chloroform-methanol [20], hexane [21], hexane-isopropanol [20] and heptane [22] solvents; however comparisons between solvent systems for oil extraction from B. braunii are not available. Chloroform was not used because of its high toxicity. Of the three lower toxicity solvents evaluated in this experiment, hexane yielded the highest oil content for both strains in all media while heptane yielded the least content. This suggests that hexane should be the preferred solvent for extraction when assessing oil production in these B. braunii strains; higher oil production was obtained with n-hexane according to [32]. Moreover, hexane-based processes have been in commercial operation for a long time. For such processes oil yields in excess of $95 \%$ can be achieved with a solvent recovery of over $95 \%$.

\section{Conclusion}

These experiments have shown that biomass production is highly influenced by the type of the medium used for culturing both Kossou-4 and Overjuyo-3 strains of B. braunii. The BG11 medium produced significantly higher growth compared to the other media after 15 days for both strains but a different biomass trend was observed when Kossou-4 and Overjuyo-3 biomass were measured indirectly using optical density in the first 6 days. Overestimation of biomass by OD measurements was associated with the presence of the oil in growth media. Dry weight assays were therefore more accurate than OD measurements for biomass estimation. Oil production was also significantly higher in BG11 medium. The same result was obtained when three different solvents were used to extract oil. Of these, hexane extracted the highest oil by weight. These results suggest that BG11 is the best growth medium while hexane is the best solvent for oil extraction for these two strains under the conditions of this experiment.

\section{Highlights}

- Study carried out on B. braunii race B strains, Kossou-4 and Overjuyo-3;

- Different media (BG11, JM and BBM-3N) were used to assess biomass yield;

- Efficiencies of different solvents for oil extraction was assessed;

- Growth measurement at ODs (680 and $750 \mathrm{~nm}$ ) affected by oil production;

- Biomass and oil production were highest in BG11;

- Overjuyo-3 produced higher biomass than Kosssou-4;

- Kossou-4 had higher oil production than Overjuyo-3;

- Hexane extraction released the highest oil concentrations in both strains.

\section{References}

[1] Costa, M.H., Yanagi, S.N., Souza, P.J., Ribeiro, A. and Rocha, E.J. (2007) Climate Change in Amazonia Caused by Soybean Cropland Expansion, as Compared to Caused by Pastureland Expansion. Geophysical Research Letters, 34, 1-4. http://dx.doi.org/10.1029/2007GL029271

[2] Cheng, J.J. and Timilsina, G.R. (2011) Status and Barriers of Advanced Biofuel Technologies: A Review. Renewable Energy, 36, 3541-3549. http://dx.doi.org/10.1016/j.renene.2011.04.031

[3] Smith, V.H., Sturm, B.S., Denoyelles, F.J. and Billings, S.A. (2010) The Ecology of Algal Biodiesel Production. Trends in Ecology \& Evolution, 25, 301-309. http://dx.doi.org/10.1016/j.tree.2009.11.007

[4] Chisti, Y. (2007) Biodiesel from Microalgae. Biotechnology Advances, 25, 294-306. http://dx.doi.org/10.1016/j.biotechadv.2007.02.001

[5] Brown, A., Knights, B. and Conway, E. (1969) Hydrocarbon Content and Its Relationship to Physiological State in the Green Alga Botryococcus braunii. Phytochemistry, 8, 543-547. http://dx.doi.org/10.1016/S0031-9422(00)85397-2

[6] Andersen, R.A. (2005) Algal Culturing Techniques. Academic Press, 578 p.

[7] Cepák, V. and Lukavský, J. (1994) The Effect of High Irradiances on Growth, Biosynthetic Activities and the Ultra- 
structure of the Green Alga Botryococcus braunii Strain Droop 1950/807-1. Algological Studies, 72, 115-131.

[8] Croft, M.T., Lawrence, A.D., Raux-Deery, E., Warren, M.J. and Smith, A.G. (2005) Algae Acquire Vitamin B12 through a Symbiotic Relationship with Bacteria. Nature, 438, 90-93. http://dx.doi.org/10.1038/nature04056

[9] Rani, H., Kumar, K. and Eswarappa, V. (2011) Effect of Nitrogen Source on the Growth and Lipid Production of Microalgae. Current Biotica, 4, 426-433.

[10] Ge, Y., Liu, J. and Tian, G. (2011) Growth Characteristics of Botryococcus braunii 765 under High $\mathrm{CO}_{2}$ Concentration in Photobioreactor. Bioresource Technology, 102, 130-134. http://dx.doi.org/10.1016/j.biortech.2010.06.051

[11] Velichkova, K., Sirakov, I. and Georgiev, G. (2012) Cultivation of Botryococcus braunii Strain in Relation of Its Use for Biodiesel Production. Journal of Bioscience and Biotechnology, 157-162.

[12] Li, Y., Moore, R.B., Qin, J.G., Scott, A. and Ball, A.S. (2013) Extractable Liquid, Its Energy and Hydrocarbon Content in the Green Alga Botryococcus braunii. Biomass and Bioenergy, 52, 103-112. http://dx.doi.org/10.1016/j.biombioe.2013.03.002

[13] Dayananda, C., Sarada, R., Usha Rani, M., Shamala, T. and Ravishankar, G. (2007) Autotrophic Cultivation of Botryococcus braunii for the Production of Hydrocarbons and Exopolysaccharides in Various Media. Biomass and Bioenergy, 31, 87-93. http://dx.doi.org/10.1016/j.biombioe.2006.05.001

[14] Ambati, R.R., Ravi, S. and Aswathanarayana, R.G. (2010) Enhancement of Carotenoids in Green Alga-Botryococcus braunii in Various Autotrophic Media under Stress Conditions. International Journal of Biomedical and Pharmaceutical Sciences, 4, 87-92.

[15] Kalita, N., Baruah, G., Dev G.R.C., Talukdar, J. and Kalita, M.C. (2011) Ankistrodesmus falcatus: A Promising Candidate for Lipid Production, Its Biochemical Analysis and Strategies to Enhance Lipid Productivity. Journal of Microbiology and Biotechnology Research, 1, 148-157.

[16] Sakamoto, K., Baba, M., Suzuki, I., Watanabe, M.M. and Shiraiwa, Y. (2012) Optimization of Light for Growth, Photosynthesis, and Hydrocarbon Production by the Colonial Microalg Botryococcus braunii BOT-22. Bioresource Technology, 110, 474-479. http://dx.doi.org/10.1016/j.biortech.2012.01.091

[17] Zhang, F., Cheng, L.H., Xu, X.H., Zhang, L. and Chen, H.L. (2013) Application of Memberane Dispersion for Enhanced Lipid Milking from Botryococcus braunii FACHB 357. Journal of Biotechnology, 165, 22-29. http://dx.doi.org/10.1016/j.jbiotec.2013.02.010

[18] Griffiths, M.J., Garcin, C., van Hille, R.P. and Harrison, S.T. (2011) Interference by Pigment in the Estimation of Microalgal Biomass Concentration by Optical Density. Journal of Microbiological Methods, 85, 119-123. http://dx.doi.org/10.1016/j.mimet.2011.02.005

[19] Sánchez Mirón, A., Contreras Gómez, A., García Camacho, F., Molina Grima, E. and Chisti, Y. (1999) Comparative Evaluation of Compact Photobioreactors for Large-Scale Monoculture of Microalgae. Journal of Biotechnology, 70, 249-270. http://dx.doi.org/10.1016/S0168-1656(99)00079-6

[20] Ryckebosch, E., Muylaert, K. and Foubert, I. (2012) Optimization of an Analytical Procedure for Extraction of Lipids from Microalgae. Journal of the American Oil Chemists' Society, 89, 189-198. http://dx.doi.org/10.1007/s11746-011-1903-z

[21] Mercer, P. and Armenta, R.E. (2011) Developments in Oil Extraction from Microalgae. European Journal of Lipid Science and Technology, 113, 539-547. http://dx.doi.org/10.1002/ejlt.201000455

[22] Eroglu, E. and Melis, A. (2010) Extracellular Terpenoid Hydrocarbon Extraction and Quantitation from the Green Microalgae Botryococcus braunii var. Showa. Bioresource Technology, 101, 2359-2366. http://dx.doi.org/10.1016/j.biortech.2009.11.043

[23] Metzger, P., Allard, B., Casadevall, E., Berkaloff, C. and Couté, A. (1990) Structure and Chemistry of a New Chemical Race of Botryococcus braunii (Chlorophyceae) that Produces Lycopadiene, a Tetraterpenoid Hydrocarbon. Journal of Phycology, 26, 258-266. http://dx.doi.org/10.1111/j.0022-3646.1990.00258.x

[24] Boonma, S., Vacharapiyasophon, P., Peerapornpisal, Y., Pekkoh, J. and Pumas, C. (2014) Isolation and Cultivation of Botryococcus braunii Kutzing from Northern Thailand. Chiang Mai Journal of Science, 41, 298-306.

[25] Mohsenpour, S.F., Richards, B. and Willoughby, N. (2012) Spectral Conversion of Light for Enhanced Microalgae Growth Rates and Photosynthetic Pigment Production. Bioresource Technology, 125, 75-81. http://dx.doi.org/10.1016/j.biortech.2012.08.072

[26] Zhu, C. and Lee, Y. (1997) Determination of Biomass Dry Weight of Marine Microalgae. Journal of Applied Phycology, 9, 189-194. http://dx.doi.org/10.1023/A:1007914806640

[27] Sawayama, S., Minowa, T., Dote, Y. and Yokoyama, S. (1992) Growth of the Hydrocarbon-Rich Microalga Botryococcus braunii in Secondarily Treated Sewage. Applied Microbiology and Biotechnology, 38, 135-138. http://dx.doi.org/10.1007/BF00169433 
[28] Eroglu, E., Okada, S. and Melis, A. (2011) Hydrocarbon Productivities in Different Botryococcus Strains: Comparative Methods in Product Quantification. Journal of Applied Phycology, 23, 763-775. http://dx.doi.org/10.1007/s10811-010-9577-8

[29] Moheimani, N.R., Cord-Ruwisch, R., Raes, E. and Borowitzka, M.A. (2013) Non-Destructive Oil Extraction from Botryococcus braunii (Chlorophyta). Journal of Applied Phycology, 25, 1653-1661. http://dx.doi.org/10.1007/s10811-013-0012-9

[30] Kalacheva, G., Zhila, N., Volova, T. and Gladyshev, M. (2002) The Effect of Temperature on the Lipid Composition of the Green Alga Botryococcus. Microbiology, 71, 286-293. http://dx.doi.org/10.1023/A:1015898426573

[31] Padovan, A. (1992) Isolation and Culture of Five Species of Freshwater Algae from the Alligator Rivers Region, Northern Territory. Australian Government Publishing Service. http://155.187.2.69/ssd/publications/tm/pubs/tm37.pdf

[32] Ferreira-Dias, S., Valente, D.G. and Abreu, J.M. (2003) Comparison between Ethanol and Hexane for Oil Extraction from Quercus suber L. Fruits. Grasas y Aceites, 54, 378-383. http://dx.doi.org/10.3989/gya.2003.v54.i4.225 


\section{Appendix}

Table A1. Composition of the different autotrophic culture media for B. braunii strains Kossou-4 and Overjuyo-3.

\begin{tabular}{|c|c|c|c|}
\hline Composition & BG11 $\left(g \cdot L^{-1}\right)$ & $\mathbf{J M}\left(\mathrm{g} \cdot \mathbf{L}^{-1}\right)$ & BBM 3N $\left(\mathrm{g} \cdot \mathrm{L}^{-1}\right)$ \\
\hline $\mathrm{NaNO}_{3}$ & 1.5 & 8.0 & 25.0 \\
\hline $\mathrm{MgSO}_{4} \cdot 7 \mathrm{H}_{2} \mathrm{O}$ & 0.075 & $5.0^{1}$ & 7.5 \\
\hline $\mathrm{CaC}_{12} \cdot 2 \mathrm{H}_{2} \mathrm{O}$ & 0.036 & - & 2.5 \\
\hline $\mathrm{KH}_{2} \mathrm{PO}_{4}$ & - & - & 17.5 \\
\hline $\mathrm{NaHCO}_{3}$ & - & 1.59 & - \\
\hline $\mathrm{K}_{2} \mathrm{HPO}_{4} \cdot 3 \mathrm{H}_{2} \mathrm{O}$ & 0.040 & 1.24 & 7.5 \\
\hline $\mathrm{Na}_{2} \mathrm{HPO}_{4} \cdot 12 \mathrm{H}_{2} \mathrm{O}$ & - & 3.6 & - \\
\hline $\mathrm{NaCl}$ & - & - & 2.5 \\
\hline $\mathrm{Ca}\left(\mathrm{NO}_{3}\right)_{2} \cdot 4 \mathrm{H}_{2} \mathrm{O}$ & - & 2.0 & - \\
\hline $\mathrm{H}_{3} \mathrm{BO}_{3}$ & 0.00286 Trace element & 0.248 Trace element & - \\
\hline $\mathrm{MnCl}_{2} \cdot 4 \mathrm{H}_{2} \mathrm{O}$ & - & 0.139 Trace element & - \\
\hline $\mathrm{MnSO}_{4} \cdot \mathrm{H}_{2} \mathrm{O}$ & 0.00181 Trace element & - & - \\
\hline $\mathrm{ZnSO}_{4} \cdot 7 \mathrm{H}_{2} \mathrm{O}$ & 0.000222 Trace element & - & - \\
\hline$\left(\mathrm{NH}_{4}\right)_{6} \mathrm{Mo}_{7} \mathrm{O}_{24} \cdot 4 \mathrm{H}_{2} \mathrm{O}$ & - & 0.1 & - \\
\hline $\mathrm{Na}_{2} \mathrm{MoO}_{4} \cdot 2 \mathrm{H}_{2} \mathrm{O}$ & 0.00039 Trace element & - & 0.004 \\
\hline $\mathrm{CuSO}_{4} \cdot 5 \mathrm{H}_{2} \mathrm{O}$ & 0.000079 Trace element & - & - \\
\hline $\mathrm{Co}\left(\mathrm{NO}_{3}\right)_{2} \cdot 6 \mathrm{H} 2 \mathrm{O}$ & 0.00049 Trace element & - & - \\
\hline Ferric ammonium citrate $\left.\left(\mathrm{C}_{6} \mathrm{H}_{8} \mathrm{FeNO}\right)_{7}\right)$ & 0.006 & - & - \\
\hline Citric acid $\left(\mathrm{C}_{6} \mathrm{H}_{8} \mathrm{O}_{7}\right)$ & 0.006 & - & - \\
\hline $\mathrm{FeCl}_{3} \cdot 6 \mathrm{H}_{2} \mathrm{O}$ & - & - & 0.097 Trace element \\
\hline $\mathrm{MnCl}_{2} \cdot 4 \mathrm{H}_{2} \mathrm{O}$ & - & - & 0.041 Trace element \\
\hline $\mathrm{ZnCl}_{2}$ & - & - & 0.005 Trace element \\
\hline $\mathrm{CoCl}_{2} \cdot 6 \mathrm{H}_{2} \mathrm{O}$ & - & - & 0.002 Trace element \\
\hline Thiamine- $\mathrm{HCl}$ (Vitamin B1) & - & 0.004 & 0.12 \\
\hline Vitamin B12 & - & 0.004 & 0.1 \\
\hline EDTA-Na ${ }_{2}$ & 0.006 & 0.225 & - \\
\hline EDTA-Fe-Na & - & 0.225 & - \\
\hline Biotin & - & 0.004 & - \\
\hline
\end{tabular}


Scientific Research Publishing (SCIRP) is one of the largest Open Access journal publishers. It is currently publishing more than 200 open access, online, peer-reviewed journals covering a wide range of academic disciplines. SCIRP serves the worldwide academic communities and contributes to the progress and application of science with its publication.

Other selected journals from SCIRP are listed as below. Submit your manuscript to us via either submit@scirp.org or Online Submission Portal.
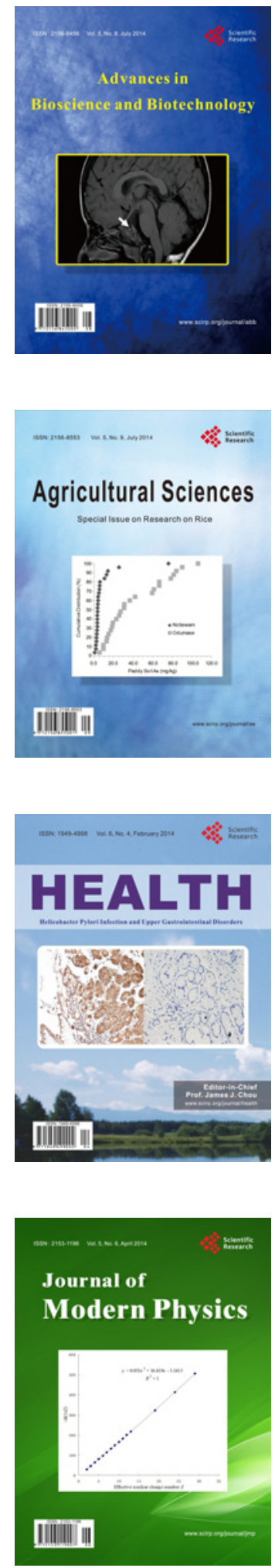
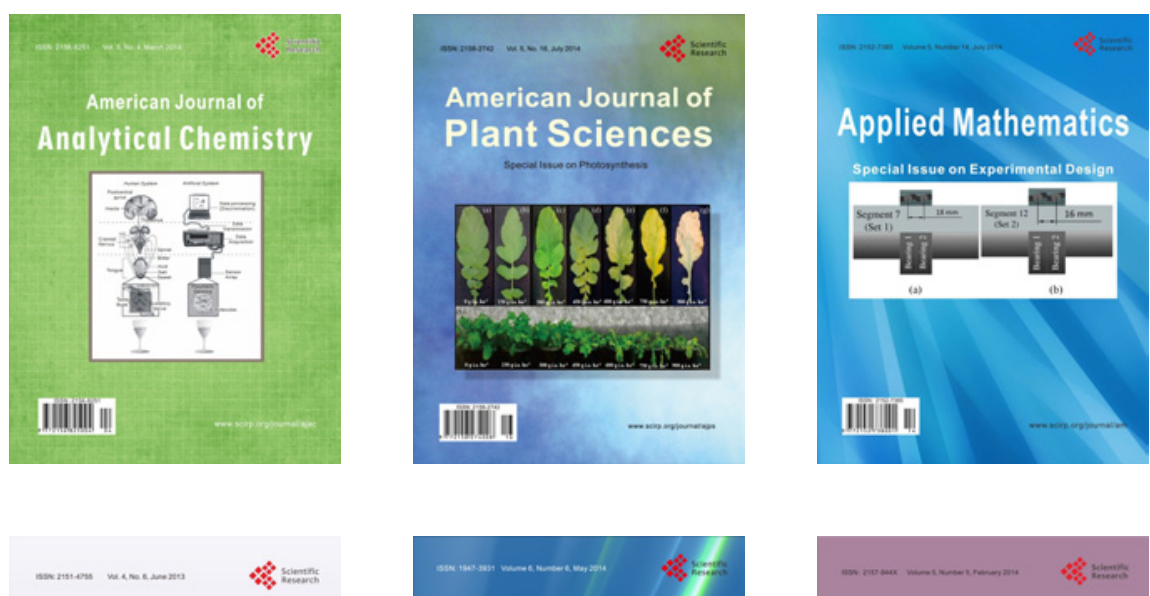

Creative Education
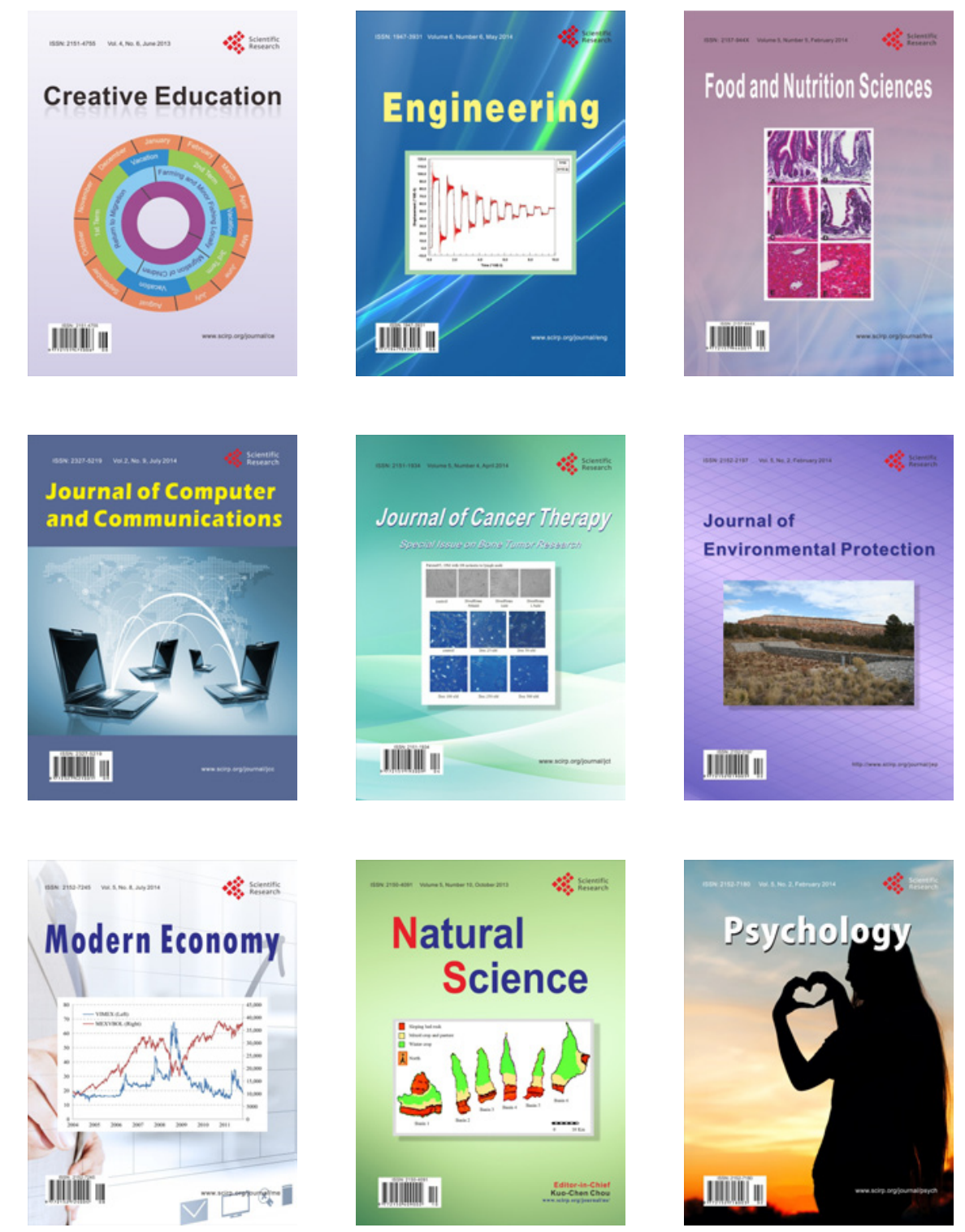